\title{
The Application of Integrated Management Information Systems of Community Service Program in Universitas Muhammadiyah Yogyakarta
}

\author{
Yulia Ariska Sudarsono *1, Nur Hayati ${ }^{2}$, Rahmat Adiprasetya, Agem Jaya Dini \\ Department of Electrical Engineering, Faculty of Engineering, Universitas Muhammadiyah Yogyakarta \\ Jl. Lingkar Selatan, Kasihan, Bantul, Daerah Istimewa Yogyakarta, 55183 Phone: (0274) 387656 \\ *Corresponding author, e-mail: yuliaasudarsono@ gmail.com ${ }^{1}$ nha.nurhayati@gmail.com $^{2}$
}

\begin{abstract}
Community service program is a compulsory subject for all students in Universitas Muhammadiyah Yogyakarta (UMY). The existing information system of community service program in UMY is still run conventionally starting from registration system, group division and work area announcement. Meanwhile, students should come and ask directly to Office of Research, Publication, and Community Service to get all the information related to the program. This current system is complicated not only for students but also for officer who manage all data about community service program in UMY. Manually administered management cause frequent errors in invading data and takes a long time to complete the activity. Researchers initiated solution to overcome this problem by implement an application of management information system. This research has developed a web-based application that can be used to manage registration, personal data filling, and periodic scheduling for students whom take the community service program. Various parameters implementation as success determinant of system creation has been applied, so obtained a decent system used. The application is based on windows operating system that easily could be accessed through web interface. System testing has been done both from users (students) side and admin. the form of the webbased application developed has followed the standard manual form so that the system can work effectively and efficiently. Copyright (C) 2017 Universitas Muhammadiyah Yogyakarta- All rights reserved.
\end{abstract}

Keywords: Management Information System, Web Based Application System, Database

\section{Introduction}

Integrated management system is one of the public service needs. One of application of management information system is the ability to obtain service with high-speed processing data, proper decision making, timing and cost savings. In additions, an integrated management system also becomes an effective and efficient tools of spreading information to related parties. Various information and integrated online-based student learning system is a form of services needed. One of the applications required by students to be connected in learning system at Muhammadiyah
University of Yogyakarta (UMY) is the development information system of community service program.

Information system related to community service program that already existing in UMY are still conventional, starting from registration system, division of group and work area announcement also the other community service program's information. Students must come directly to Office of Research, Publication, and Community Service to get all the information. This is not only complicates the students but also Office of Research, Publication, and Community Service as a institution that manage the all data of community 
service program in UMY. Manually administered management cause frequent errors in invading data and takes a long time to complete the activity. The ineffectiveness from this conventional system that underlies the authors to conduct research so the problem expected to be solved.

The purpose of this partnership research is the establishment of cooperation between lectures and students to realizing an online administration recording system or commonly referred to as a management information system for community service program service in Muhammadiyah University of Yogyakarta. This development service system of community service program expected to help Office of Research, Publication, and Community Service performance in data management and spreading information. In addition, this service also facilitate students in registration process and getting information related to community service program.

Ainur Rafik et al conducted research about "Web-based Inventory Information System with CodeIgniter Framework in Electrical Engineering Laboratory of UMY" [1]. This research aims to develop laboratory inventory information system software in accordance with the needs of Electrical Engineering Laboratory of Muhammadiyah University of Yogyakarta. Besides, this research also intend to know the quality of laboratory inventory information system in Electrical Engineering Department of UMY based on software quality standard. The result of this research are web-based laboratory inventory information system software with codeigniter framework using an architecture that is 2 actors, 26 use-case, 5 class, single database with 7 data table, and interface design for admin and user.

Meanwhile, Ana N. Cahyanti and Bambang E. Purnama have conducted on research "Management Information System Development in Puskesmas Pekis Baru Newangan" [2]. This research generate a software application that can help Puskesmas Pakir Baru during the patients registration process so that can facilitate officers to managing and searching data as well as in making patients medical records.

Yonatan L. Prihartanto has completed research related to "Agenda Management Information System in Badan Pelayanan Perijinan Terpadu
Kabupaten Karanganyar" [3]. This system purposes is to change the old system that is still conventional to system based on computerized and web to facilitate in processing incoming and outgoing mail in Badan Pelayanan Perijinan Terpadu Kabupaten Karanganyar. This system contains procedures such as reception, creation, storage, documentation to mail verification.

\section{Underlying Theories}

\section{II.1. Management Information System}

According to James Alter, management informatioan system can generally be interpreted as combination of human, information, information technology, and work procedures organized to achieve goals within an institution [4]. Meanwhile, according to Kenneth C. Laudon and Jane P. Laudon in their book Management Information System Managing The Digital Firm, Tweflth Edition mentioned that the role information systems in the bussiness world today is very important [5]. In harmony with the previous, Raymond McLeod Jr. And George P. Schell in their book Management Information System stated that the computer-based information system development is needed tosupport the goals and strategic plans of an organization. Therefore it can almost be stated that in this $21^{\text {st }}$ century, business without information technology becomes an unusual things. In order to balance the rapid development of informatioan technology in business proceess both in academic and non-academic instituions, it is necessary to support management of good management. Management thar integrated in both human resources and utilization of information technology need to be harmonized, so tht can create an ideal business environment and support one another.

The same thing from one business process also occurs in an educational institution. There are many things that need to be synergized between on servive in particular university with its users in this case are students, educators and educational staff. Management information system in a college is very useful for stakeholders in a campus. Integrated services make it easy for educators to interact with students, as well as between educators and educational staff and between students and educational staff. The existence of integrated 
management information system makes student services can be more effective and efficient. The computerization of various services provided by the university can also create a modern campus environment with tecgnological sophistication being implemented.

\section{II.2. Interned-based Web Application}

Based on information obtained by researchers from one online source web page Ministry of Communications and Information of the Republic of Indonesia, mentioned that the population of internet users or commonly reffered to as netter Indonesia in 2014 reched 83.7 million people [7]. The data is calculated by e-Marketer market reseach institute, which in 2017 is predicted to increase to 112 million people. From figure 2.1 it appears that Indonesia is ranked in sixth countries with the most internet users in the world.
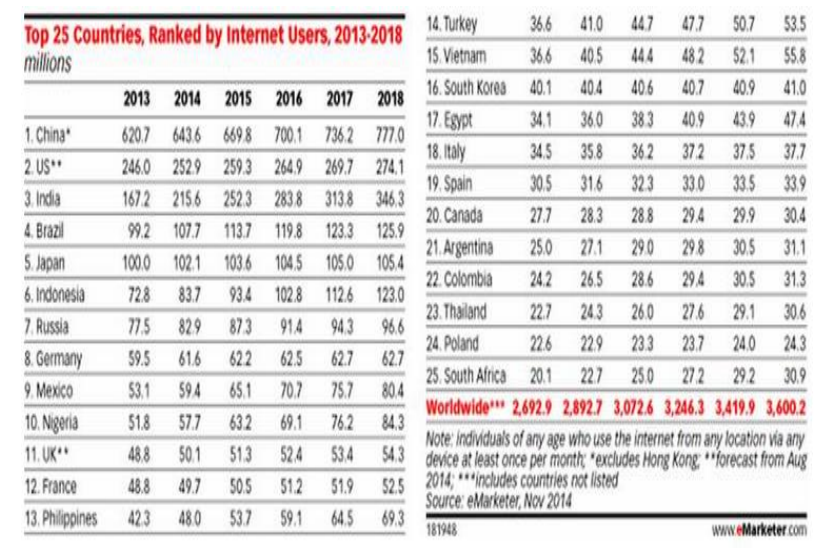

Fig. 1. Country rank data with the highest internet users [Source : eMarketer]

HTTP is a protocol that specifies the rules that web browsers need to follow in requsting or retrieving a document and by the web server in providing the documents requested by the browser. HTTP is a standard protocol web-based comunications until this day. In its activities HTTP in cooperation with the URL's support. Uniform Resource Locator or abbreviated URL is an address that determines the location of information file on a web server. Where the address consist of protocol used a browser to retrieve information, name of the server computer where the information is stored as well as the path and file name of an information.

\section{Proposed System Design}

In this system planning section, researchers have identified users candidate of the application. Determination users candidate is done by making observations based in the existing problems analysis in the currently running system. Figure 2 below is a flowchart of the existing system of community service program students registration.

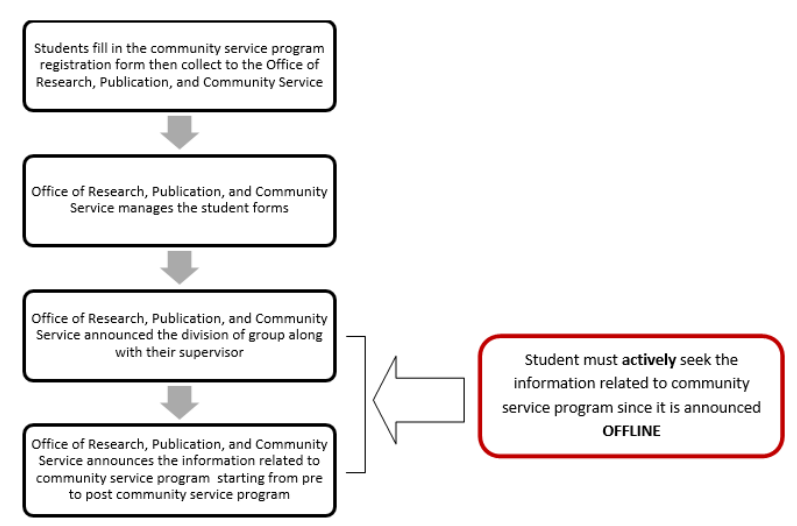

Fig. 2. Community Service Program Registration Flowchart

Based on figure 2 above shows that the system involves the students as a user and LP3M acts as admin. The system built alsa has a candidate userd classification as exixting plus a general user.

\section{III.1. Proposed Systen}

Determination of the subject or prospetive users is done by making observations based on the analysis of existing problems within the currently running system. There are the classification result of the candidate user's identity along with their respsective access rights.

a. Admin

Admin in this system is someone who has been assined to manage everything in the system. Admin has full roghts to the system that can do create, read, update and delete or commonly called CRUD. b. User

Users in this system are students who have registered as community service program candidates and registered to create an account. Users can make CRUD limited to their personal information on the account profile page.

c. Non-user (general user)

Non-users are site visitors be it UMY civitas or the outside community who can only see the homepage 
and do not have any access roghts.

The students profile as defined above has the abilty to register as a community service program participant candidate. The overall system of community service program registration can be seen in Figure 3 below. That diagram shows the flowchart of community service program management informatioan system application that refers to the step hoe students enrolls as a candidate community service program participan through online web based system application.
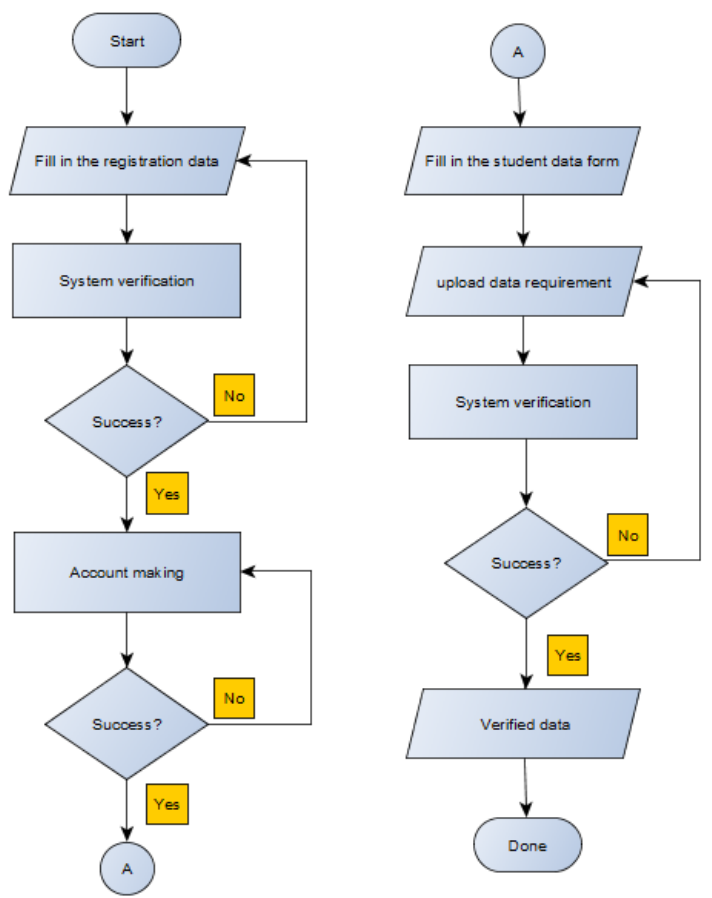

Fig. 3. Flowchart of community service program information management system application

Based on the design floew above then, the research team determined thet the operating system is windows with XAMPP server support and MySQL. Next to the coding on the server side will be used PHP programming language and on the client side using HTML web programming langauage.

In the system built design, researchers distinguish he access rights between students and admins. Administrators have higher privilege (access privileges) than normal users, where there is a ability to manage user data (students) in accordance with the the rules set by Office of Research, Publication, and Community Service institution. This privilege distinction has bees adjusted to the rights and responsibilities of each party. In general, the data flow logic of teh system usage proccess from the students side as a service user and admin looks in Figure 4 below.

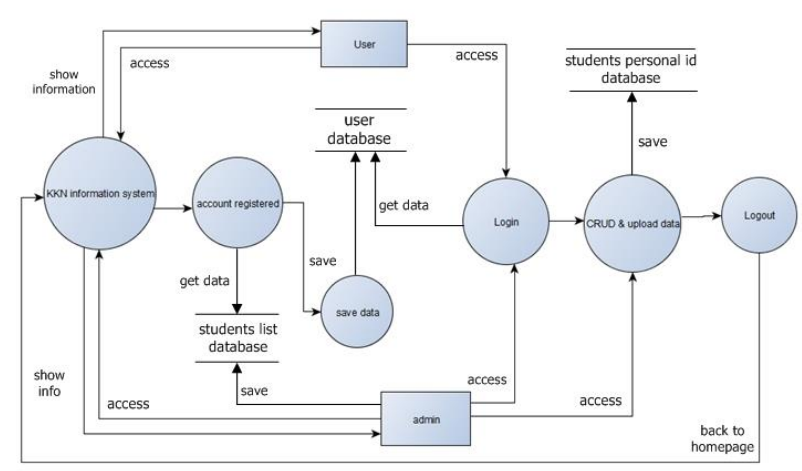

Fig. 4. Data flow logic of utilization of web-based community service program system application.

The database design in this system is designed based on the needs of the system as well as the needs of each user. Here is a database design that supports the system.

Table 1. Participants Personal Data Table

\begin{tabular}{|l|c|c|c|c|}
\hline Field & Type & Lenght & Extra & Primary \\
\hline No & varchar & 10 & & \\
\hline Student_ID & varchar & 11 & & yes \\
\hline Name & varchar & 50 & & \\
\hline Faculty & varchar & 50 & & \\
\hline Major & varchar & 50 & & \\
\hline Place_of_birth & varchar & 50 & & \\
\hline Date-of-birth & date & & & \\
\hline Gender & varchar & 10 & & \\
\hline Address & text & & & \\
\hline Email & varchar & 50 & & \\
\hline No_hp & varchar & 30 & & \\
\hline Size_Shirt & varchar & 30 & & \\
\hline Program_Periode & varchar & 30 & & \\
\hline
\end{tabular}

Table 2. Administrator Table

\begin{tabular}{|l|l|l|l|l|}
\hline Field & Type & Lenght & Extra & Primary \\
\hline ID & Int & 5 & & yes \\
\hline usernama & varchar & 20 & & \\
\hline Password & varchar & 50 & & \\
\hline
\end{tabular}

\section{III.2. Architecture Design System}

Architectural design on this system design using Unified Modeling Language (UML) which aims to visualize, specify, build and documentation of a 
software development system. Architectural design depiction in the form of use case diagram that descirbes the interaction between the system with administrators and users. Use case diagram consists of actor and its description. Based on the results of needs analysis obtained architectural design which illustrated using the use case diagram in UML notation consists an admin and user. Admin is a user in the system that has full access roghts to the system. Here are the functios that can be accessed bt the admin.

Table 3. Description of administrator use case diagram

\begin{tabular}{|c|c|c|}
\hline $\begin{array}{c}\text { Activity } \\
\text { Categories }\end{array}$ & Activity & Function Description \\
\hline \multirow[t]{2}{*}{$\begin{array}{l}\text { System } \\
\text { Administrator }\end{array}$} & $\log$ in & $\begin{array}{l}\text { enter to the system as an } \\
\text { admin through the } \\
\text { detection of username } \\
\text { and password }\end{array}$ \\
\hline & Log out & $\begin{array}{l}\text { exit the system as an } \\
\text { admin }\end{array}$ \\
\hline \multirow{4}{*}{$\begin{array}{l}\text { User } \\
\text { Management }\end{array}$} & $\begin{array}{l}\text { Add } \\
\text { user }\end{array}$ & $\begin{array}{l}\text { add students data for } \\
\text { account verification by } \\
\text { user and add students } \\
\text { account manually }\end{array}$ \\
\hline & $\begin{array}{l}\text { Shows } \\
\text { user }\end{array}$ & $\begin{array}{l}\text { display list of students } \\
\text { and their related } \\
\text { information }\end{array}$ \\
\hline & $\begin{array}{l}\text { Edit } \\
\text { user }\end{array}$ & $\begin{array}{l}\text { edit user data in the } \\
\text { database }\end{array}$ \\
\hline & $\begin{array}{l}\text { Delete } \\
\text { user }\end{array}$ & $\begin{array}{l}\text { to delete user data in the } \\
\text { database }\end{array}$ \\
\hline $\begin{array}{l}\text { Mail } \\
\text { managaement }\end{array}$ & $\begin{array}{l}\text { Shows } \\
\text { mail }\end{array}$ & $\begin{array}{l}\text { display incoming mail or } \\
\text { messages to the database } \\
\text { in tabular form }\end{array}$ \\
\hline \multirow{3}{*}{$\begin{array}{l}\text { News } \\
\text { Management }\end{array}$} & $\begin{array}{l}\text { Add } \\
\text { news }\end{array}$ & add news to the database \\
\hline & $\begin{array}{l}\text { Shows } \\
\text { news }\end{array}$ & $\begin{array}{l}\text { displays news in the } \\
\text { database to the homepage } \\
\text { page }\end{array}$ \\
\hline & $\begin{array}{l}\text { Delete } \\
\text { news }\end{array}$ & $\begin{array}{l}\text { delete the existing news } \\
\text { in the database }\end{array}$ \\
\hline
\end{tabular}

From the description of the use case table above can be described use case as follows :

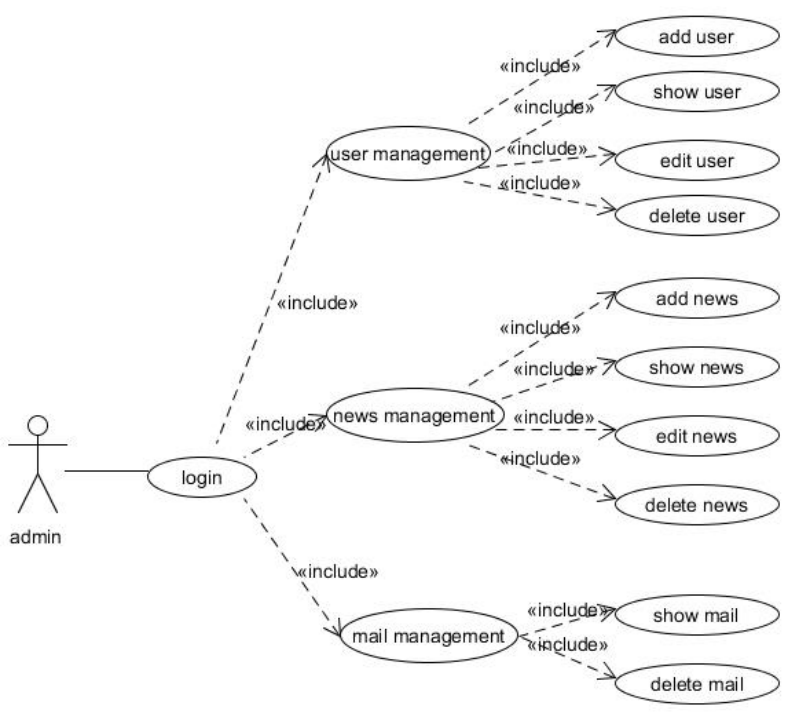

Fig 5. Admin Use Case Diagram

Users use case diagram with a status of account owner are students who have registered an account in the system, the function that belongs to the access rights is shown in table 4 below :

Table 4. Description of user use case diagram

\begin{tabular}{|l|l|}
\hline Use Case & \multicolumn{1}{|c|}{ Function Description } \\
\hline Register & $\begin{array}{l}\text { register to the system in order to make } \\
\text { an account }\end{array}$ \\
\hline Log in & $\begin{array}{l}\text { enter the system as a user with system } \\
\text { verification based on student ID number } \\
\text { and password }\end{array}$ \\
\hline Log out & $\begin{array}{l}\text { exit as a user and back to the homepage } \\
\text { page }\end{array}$ \\
\hline Add data & $\begin{array}{l}\text { add student personal information } \\
\text { according }\end{array}$ \\
\hline Edit data & edit personal data \\
\hline $\begin{array}{l}\text { Upload } \\
\text { file }\end{array}$ & $\begin{array}{l}\text { upload files according to the requested } \\
\text { requirments }\end{array}$ \\
\hline $\begin{array}{l}\text { Download } \\
\text { file }\end{array}$ & $\begin{array}{l}\text { download related file as the output of the } \\
\text { registration system }\end{array}$ \\
\hline
\end{tabular}

From the description of the use case table above can be described as follows : 


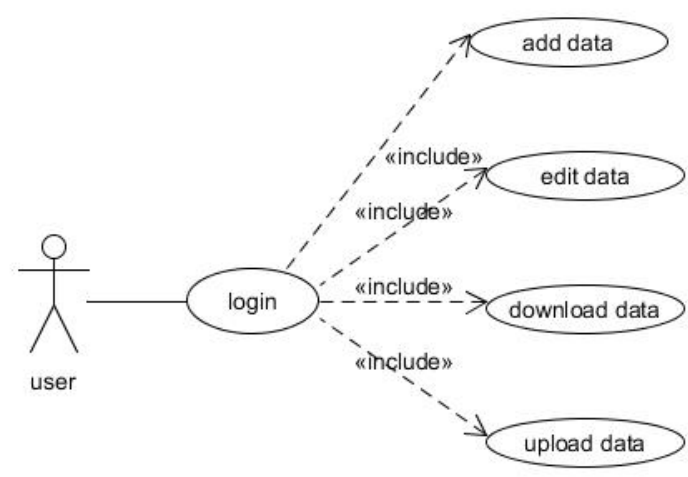

Fig 6. User Use Case Diagram

\section{Result and Analysis}

Based on the design that occurred then generated an integrated information system that can be accessed through a web browser. In the system divided into several parts that need to be analyzed with. Here is a list of general system functional requirements that include login and logout capabilities, displaying, adding, modifying and deleting data, following by uploading and downloading data. Next on the system input capabilities the user can memasuskan and save data, users can upload files and admins can add and store data. In the process capability, the system can display user data on the page that has been created, enter data into the system database for users, store data into the system database for users, upload and download files on the user page. Can also display data on admin page, inserting, storing and deleting data into database for admin. In the output section of the system created to be able to display user data, displays download files, user data, user data for admin and displays user upload data files.

\section{IV.1. The Database of Management Information System of Community Service Program}

In this system, the researcher uses the phpMyAdmin feature provided by XAMPP as the localhost database server. Database of management information system Community Service Program consists of nine tables, namely: admin, news, participant data, student ID number, messages, users, photos, letters, and transcripts.

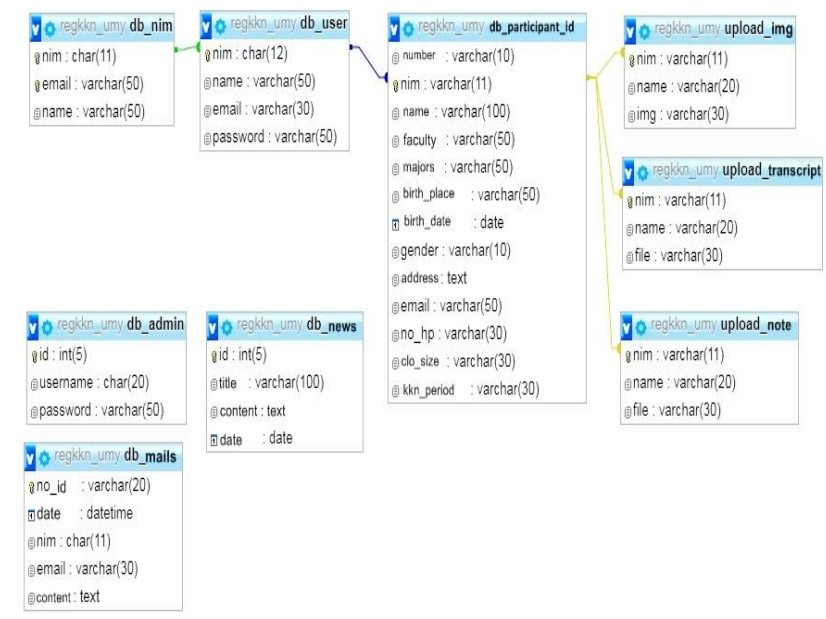

Fig. 7. Database relation at the application system

The database table admin consists of 3 fields, namely id (primary key), username and password. While News table consists of 4 fields, namely id (primary keyprimary key), title, content and date. The participant data table consists of 13 fields, ie serial number, nim (primary key), name, faculty, department, place of birth, birth date, gender, address, email, mobile phone number, clothing size, and period of Community Service Program. The student ID number table consists of 3 fields, namely ID number (primary key), email (unique) and name. Message table consists of 5 fields, which are serial number (unique), date, student ID number, email, and message. The user table consists of 4 fields, namely student ID number (primary key), name, email and password. Table photo consists of 3 fields, namely student ID number (primary key), name and image. Transcript table consists of 3 fields, namely student ID number (primary key), name and file. All of the above tables are connected to each other, where the picture of the relation between the tables in the system database looks at the figure $\mathrm{x}$ above.

\section{IV.2. Web development using bootstrap framework}

The programming process is done using PHP version 5 with the Bootstrap-3.3.7 framework. Writing program using Sublime Text 3 Build 3126 editor application. Main view is General Homepge which is the initial page when visitors access this website. All users both admin, user and non user can access this page. On page ii consists of home, about, news and contact. Menu details on each navbar are as follows. On home or main page is 
displayed when the URL address is typed where on this page there are navbar menu (home, about, news and contact), button (register and login), carousel as slide show images, content, and footer.

At the top right of this page there is a register button that serves as a student enrollment form to create a community service program participant account. This page is accessible to all users but only students who are registered as potential community service program participants can use it. The data requested in the text box must be filled in accordance with the command, if the data is filled wrong it will appear alert or warning.

The login page is accessible to all users but only registered accounts can use it. On this page there is a text box in the form of username and password to be filled in accordance with the registered data. If the filled data does not match an alert will appear as a warning that an input error has occurred.

The next web view is User Profile. This page can only be accessed by registered account owners, which are divided into several tabs. This page contains the flow of community service program registration as well as requirements that must be adhered to community service program participants. On this page there is a menu consisting of home, ID Form, Upload Form, Download Form, and logout. The Form ID page shows the account owner's own data. If the account owner has not done the form filling, then the page will display blank form or blank form. To fill an empty form or change existing data, the user can press Edit button under the form then the system will redirect to Edit Data Self page.

Page Upload Form consists of 3 types of upload requests are photo files, student transcripts that indicate that the student has met the minimum credits for the implementation of community service programs and health certificate students concerned. Uploaded files must match their respective extensions, the system will display alerts in case of input errors. This page displays the text box beirisi data self-participant community service program UMY, under the text box there is a button Download Form to download the proof of registration community service program in the form of files with extension *. Pdf. Next User who will exit the web page can choose the Logout menu that will men-direct back to the main page and end the session.

The next page view is the admin access page or priviledge access administrator. On this page there is a text box of username and password for admin. If the filled data does not match an alert will appear as a warning that an input error has occurred. Administrators who are already logged in will get a view of the Admin Dashboard page. The admin home page has the main navigation to the left of the hamalan. Navigation will go to the data pages that will be managed by the admin. One of the menus in this view is a registered student data page containing a list of students who have registered as candidates for the community service program. This page lists the names of UMY students who have added community service programs in their study plan system. In this admin area can add data to change data, and delete data. Alert box will appear when admin pressing delete button.

Add Data feature allows the admin in adding new data that is also connected to the database so that the data entered directly stored didatabase. The edit feature makes it easy for the admin to update existing data and directly store it in the database. Delete feature to delete data that is not needed or outdated. This feature not only deletes on the show page but also deletes the existing data didatabase. The administrator features a user data page where this page contains account data that has been registered. In this page, admins can add data, change data and delete data. Alert box will also appear when the admin will delete the data in the table. In the administrator page there is also a tab that is a data requirement. This page contains data files that have been uploaded or uploaded by community service program participants. Through this page admin can only see the data without being able to add, change, or delete data. Delete data is done through its localhost database directly.

\section{Conclusion and Future Research}

Based on the analysis results, the following conclusions can be drawn that Management information system application of community service program at Muhammadiyah University of Yogyakarta was successfully created. The created application system contains online-based community service program information notification on local network. Registration through 
local network has been succesfullt tested by some students. Application is capable to differentiating user access consisting a general publis, students and admin or manager. System is capable to receiving automatic data upload from community service program candidate participants who have registered. Data download feature has optimally functioning to download community service program data students

Recommendation for the next application development is synchronize students data to online study plan system to facilitate data retrieval of user or students information.

\section{Acknowledgements}

This work was supported by LP3M Universitas Muhammadiyah Yogyakarta.

\section{References}

[1] A. Rafik, "Sistem Informasi Inventaris Laboratorium Teknik Elektro UMY Barbasis Web dengan Framework Codeigniter", Universitas Muhammadiyah Yogyakarta, 2017,

[2] Cahyanti, Ana Nur dan B. E. Purnama," Pembangunan Sistem Informasi Manajemen Puskesmas Pakis Baru Nawangan", Speed - Sentra Penelitian Engineering dan Edukasi, Vol. 4, No 4, 2012.

[3] Prihartanto, Yonatan Liliek," Sistem Informasi Manajamen Agenda Pada Badan Pelayanan Perijinan Terpadu Kabupaten Karanganyar", Speed - Sentra Penelitian Engineering dan Edukasi, Vol. 3. No. 3, 2011.

[4] Alter Steven, "Information System: A Management Perspective", The Benjamin P ublishing Company Inc, 1992.

[5] Kenneth C. Laudon and Jane P. Laudon , "Management Information System Managing the Digital firm", Twelfth Edition, Prentice hall, 2012.

[6] Raymond McLeod Jr. and George P. Schell, "Management Information Systems, Ninth Edition", Prentice Hall, 2003.

[7] Ministry of Communication and Informatics of the Republic of Indonesia (2017). Data and News Articles. Accessed on 22nd July 2017. [Online]. Available: https://kominfo.go.id/

\section{Authors' information}

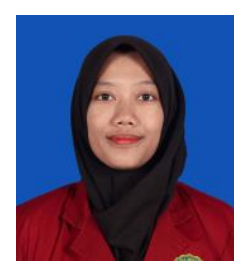

Yulia Ariska Sudarsono was born in Fakfak on July 18th 1994. She has graduated from electrical engineering major in Muhammadiyah University of Yogyakarta.

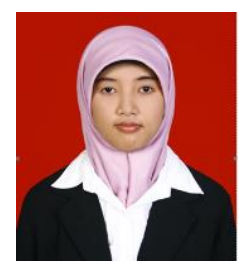

Nur Hayati currently is a lecturer and researcher in Universitas Muhammadiyah Yogyakarta. She graduated from telecommunication engineering major in EEPIS-ITS Surabaya and continued her master degree in electrical engineering major Universitas Indonesia Depok.

Nur Hayati, S.ST. M.T. are member of senior instructor in Cisco Networking Academy Program and Unity of Indonesian Engineers (Persatuan Insinyur Inndonesia) 